


\title{
Recuperación de la Real Fábrica de Paños de Brihuega, Guadalajara
}

\author{
Recovery of the Real Fábrica de Paños de \\ Brihuega, Guadalajara
}

\author{
Recuperação da Real Fábrica de Paños de \\ Brihuega, Guadalajara
}

The town of Brihuega, with 2,400 inhabitants, is located at the center of the province of Guadalajara, thirty kilometers from the capital of the province and one hundred kilometers from Madrid. It is a typical Alcarria town, with the peculiarity that a high percentage of its buildings are listed as part of the Historic Artistic Heritage Catalog and, consequently, are highly protected. The most relevant elements of its built heritage are the walls, the Arch of Cozagón, the churches of San Felipe, San Miguel and Santa María de la Peña, the castle of Spanish-Muslim origin, which houses the cemetery, and the Bullfighting Arena. The Village has
Brihuega, que cuenta con cerca de 2.400 habitantes, se encuentra en el centro de la provincia de Guadalajara, a poco más de treinta kilómetros de la capital de la provincia y a cien kilómetros de Madrid. Se trata de un típico pueblo alcarreño, con la particularidad de que un elevado porcentaje de sus edificios forman parte del Catálogo de Patrimonio Histórico Artístico y, en consecuencia, cuentan con un elevado nivel de protección. Los elementos más destacados de su patrimonio construido son las murallas, el Arco de Cozagón, las iglesias de San Felipe, San Miguel y Santa María de la Peña, el castillo de origen hispanomusulmán, que alberga en su interior el

\author{
Juan de Dios \\ de la Hoz Martínez
}

Brihuega, com aproximadamente 2400 habitantes, encontra-se no centro da província de Guadalajara, a pouco mais de trinta quilómetros da capital da província e a cem quilómetros de Madrid. Trata-se de uma localidade típica de Alcarraria, com a particularidade de que uma elevada percentagem dos seus edifícios forma parte do Catálogo do Património Histórico Artístico e, consequentemente, contam com um elevado nível de proteção. Os elementos mais destacados do seu património construído são as muralhas, o Arco de Cozagón, as igrejas de San Felipe, San Miguel e Santa María de la Peña, o castelo de origem hispano-muçulmano,

< Orthophoto of the restored roofs | Ortofoto de las cubiertas restauradas | Ortofotografia das coberturas restauradas (Joaquín Zamora)

$>$ Photo of the lavender fields of Brihuega | Fotografía de los campos de lavanda briocenses | Fotografia dos campos de lavanda de Brihuega (Juan Carlos Gómez, http://www. turismobrihuega.com/index.php/lavanda)

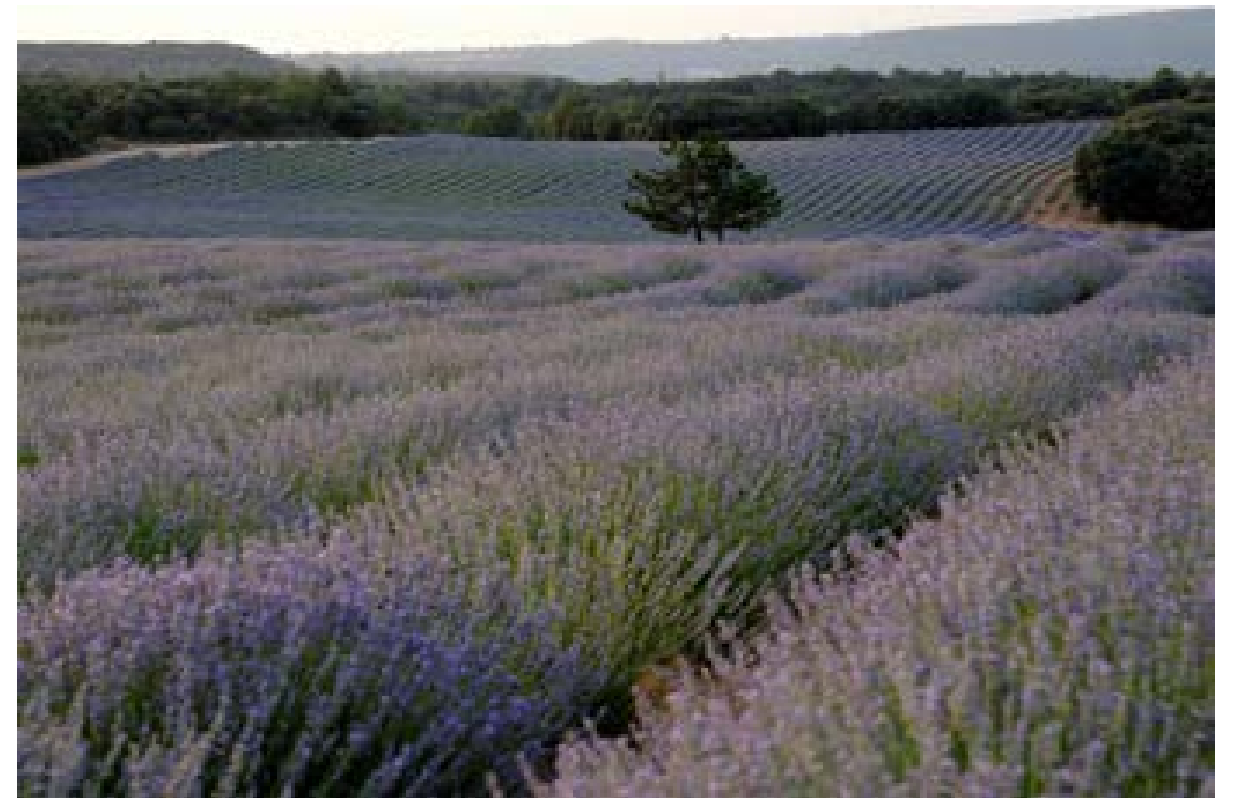


become famous in recent years thanks to its spectacular lavender fields and its annual festival.

The Real Fábrica de Paños, built under the reign of Carlos III, is located on the highest part of the Village, dominating the old quarter and surrounded by gardens, on a terrace overlooking the Tajuña Valley. It is one of several textile factories promoted by King Carlos III. It reached its highest production during the 18th Century, and subsequently fell into decline. The complete state of abandonment and deterioration in which it finds itself today has accelerated the need for an intervention to avoid its complete ruin. For this reason, the City of Brihuega acquired the property early in 2017 cementerio, y la Plaza de Toros. La Villa ha alcanzado gran fama en los últimos años por sus espectaculares campos de lavanda y el festival que se celebra anualmente.

La Real Fábrica de Paños, construida durante el reinado de Carlos III, se encuentra situada en la parte más alta de la Villa, dominando el conjunto del casco antiguo y rodeada de jardines, sobre una terraza que domina el valle del Tajuña. Se trata de una de las varias fábricas textiles promovidas por el Rey Carlos III. Alcanzó su mayor nivel de producción durante el siglo XVIII y cayó posteriormente en decadencia. El completo abandono y el deterioro con que llegó a nuestros días aceleraron la necesidad de intervenir sobre ella para que alberga no seu interior o cemitério, e a Plaza de Toros. A Villa alcançou grande fama nos últimos anos pelos seus espetaculares campos de lavanda e o festival que se celebra anualmente.

A Real Fábrica de Paños, construída durante o reinado de Carlos III, encontra-se situada na parte mais alta da Villa, dominando o conjunto do casco antigo e rodeada de jardins, sobre um terraço que domina o vale do Tajuña. Trata-se de uma das várias fábricas têxteis promovidas pelo Rei Carlos III. Alcançou o seu maior nível de produção durante o século XVIII e caiu posteriormente na decadência. $\mathrm{O}$ completo abandono e o deterioro com que chegou aos nossos dias aceleraram a necessidade de intervir sobre a fábrica

Panoramic view of Brihuega; close up, the Church of Santa María, in front of the Castle. Bottom right, after the line of cypress trees, the Cloth Factory can be glimpsed Imagen panorámica de la Villa de Brihuega; en primer plano, la Iglesia de Santa María, delante del Castillo. Al fondo a la derecha, tras la hilera de cipreses, se intuye la Fábrica de Paños I Imagem panorâmica da Villa de Brihuega; em primeiro plano, a Igreja de Santa María, à frente do Castelo. Ao fundo à direita, depois da fila de ciprestes, pensa-se que seja a Fábrica de Paños (Joaquín Zamora)

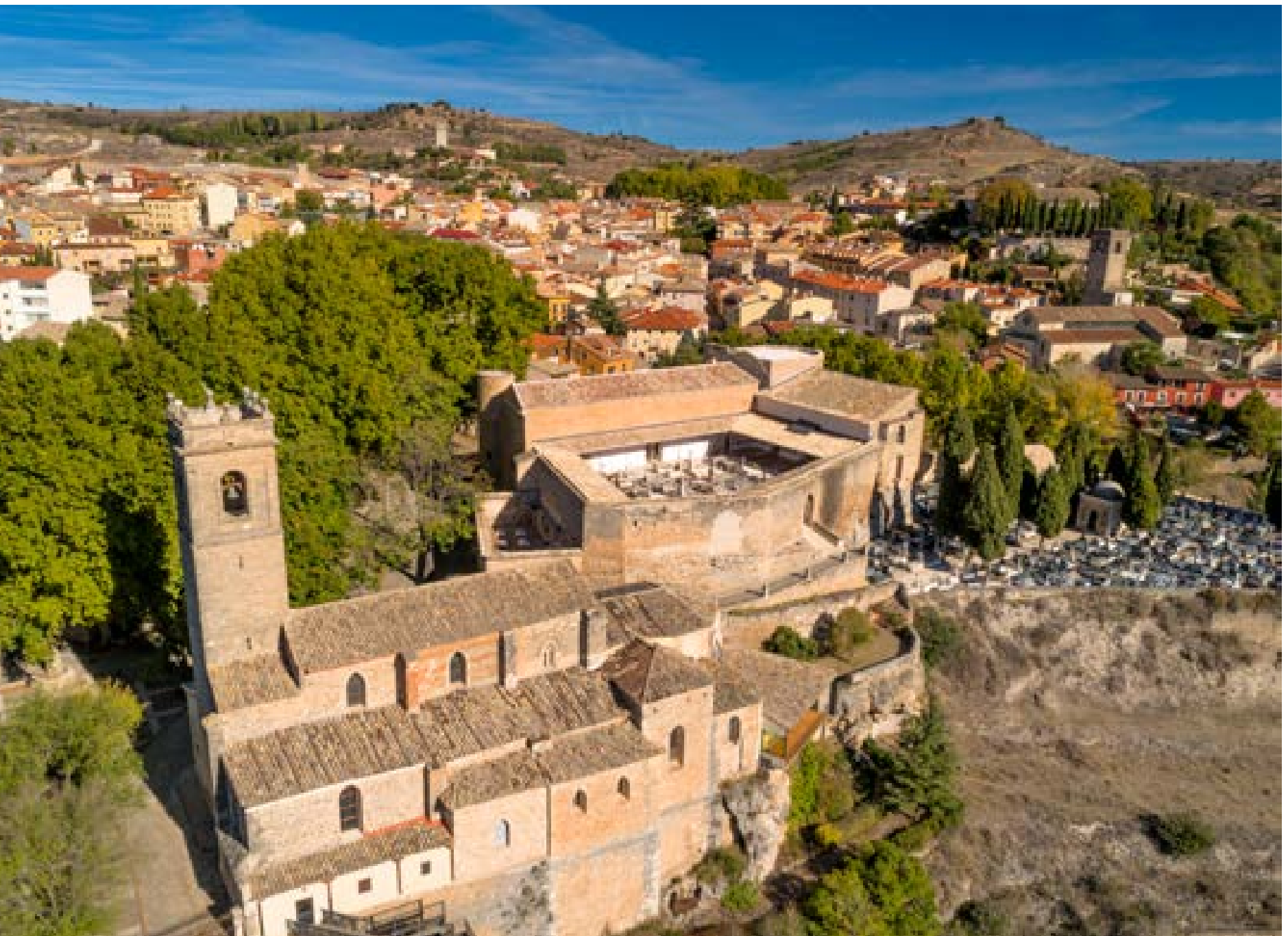




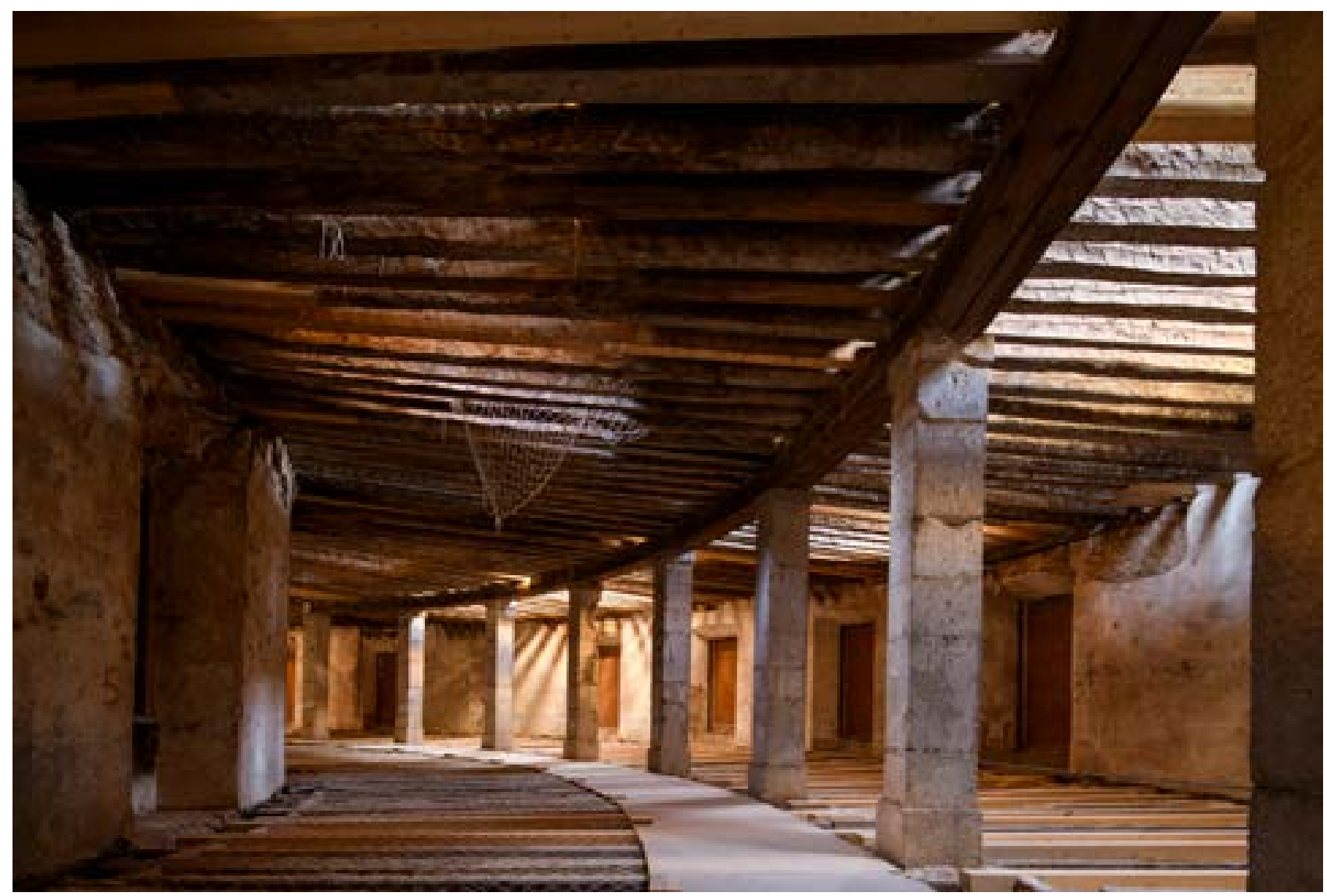

State of conservation of the interior of the first floor before the intervention | Estado de conservación del interior de la primera planta previo a la intervención | Estado de conservação do interior da planta primeira antes da intervenção

in order to undertake an integral conservation, and the functional revitalization and enhancement of the building to be enjoyed as a Heritage Asset by the inhabitants of the town and all its visitors.

In 1750, during the reign of Fernando VI, the decision was made to build a Royal Cloth Factory in Brihuega, as a branch of the Guadalajara factory. Brihuega was considered an ideal location due to the presence of the Tajuña River and the abundance of natural resources such as water and wood, and the availability of skilled labor. Construction started one year later, under the direction of architect Manuel de Villegas. Shortly before its completion, twenty looms were already in operation, distributed along several houses in the Village. evitar su ruina completa. Por este motivo el Ayuntamiento de Brihuega adquirió la propiedad a principios de 2017, con el fin de llevar a cabo una conservación integrada, así como la revitalización funcional y la puesta en valor del edificio para su disfrute como Bien Patrimonial por parte de los habitantes del pueblo y de cuantos lo visiten.

Fue en 1750, durante el reinado de Fernando VI, cuando se decidió ubicar en Brihuega una Real Fábrica de Paños como sucursal de la ya existente en Guadalajara. Brihuega se consideró un lugar idóneo debido a la presencia del río Tajuña y a la abundancia de recursos naturales como agua y leña, así como por su fácil acceso a mano de obra especializada. Un año más tarde, bajo la dirección del arquitecto Manuel de Villegas, comenzaron las obras de construcción. Poco tiempo después, antes de su finalización, ya estaban en funcionamiento veinte telares repartidos por diversas casas de la Villa. para evitar a sua ruina total. Por este motivo, a Câmara Municipal de Brihuega adquiriu a propriedade no principio de 2012 a fim de efetuar uma conservação integrada, bem como a revitalização funcional e a valorização do edifício para usufruto como Bem Patrimonial por parte dos habitantes da localidade e de todos que a visitem.

Foi em 1750, durante o reinado de Fernando VI, quando se decidiu instalar em Brihuega uma Real Fábrica de Paños como sucursal da já existente em Guadalajara. Brihuega foi considerada o local idóneo devido à presença do rio Tajuña e à abundancia de recursos naturais como água e lenha, bem como pelo seu acesso fácil à mão de obra especializada. Um ano mais tarde, sob a direção do arquiteto Manuel de Villegas, começaram as obras de construção. Pouco tempo depois, antes da sua finalização, já estavam em funcionamento vinte teares repartidos por diversas casas da Villa. 
The activity increased, and early in 1752, the number of looms had increased to thirty, and by mid-1753 there were fifty looms in operation. The number of workers at the time reached 353 , including journeymen, masters, weavers and wool workers, among others. During the following years, already under the reign of Carlos III, the factory continued to expand; by 1787 , there were a hundred looms in operation at the same time, which made this Factory one of the most prestigious in the country.
La actividad fue creciendo, pues a principios de 1752 los telares en uso aumentaron su número a treinta, $y$ alcanzaron la cifra de cincuenta a mediados de 1753. El número de trabajadores ascendía entonces a 335, entre oficiales, maestros, tejedores y cardadores, entre otros. Durante los años siguientes, reinando ya Carlos III, siguieron ampliando el conjunto, de tal manera que en 1787 ya había hasta cien telares en funcionamiento de manera simultánea, lo que convirtió a esta Fábrica en una de las más prestigiosas del país.
A atividade foi crescendo, pois a princípios de 1752 os teares em uso aumentaram o seu número para trinta, e alcançaram os cinquenta a mediados de 1753. O número de trabalhadores ascendia então a 335, entre oficiais, mestres, tecedores e cardadores, entre outros. Durante os anos seguintes, já no reinado de Carlos III, continuaram a ampliar o conjunto, de tal forma que em 1787 já havia até cem teares em funcionamento de forma simultânea, convertendo esta Fábrica numa das mais prestigiosas do país.

1: State of conservation of the interior of the ground floor before the intervention 2: Recovery of the old ground floor flooring, recovery of the closed openings and new arrangement of the jars | 1: Estado de conservación del interior de la planta baja previo a la intervención 2: Recuperación del antiguo solado de planta baja, apertura de los vanos cegados y nueva disposición de las tinajas | 1: Estado de conservação do interior da planta térrea antes da intervenção 2: Recuperação do antigo lajeado da planta térrea, abertura dos vãos cegos e nova disposição das ânforas (2: Joaquín Zamora)
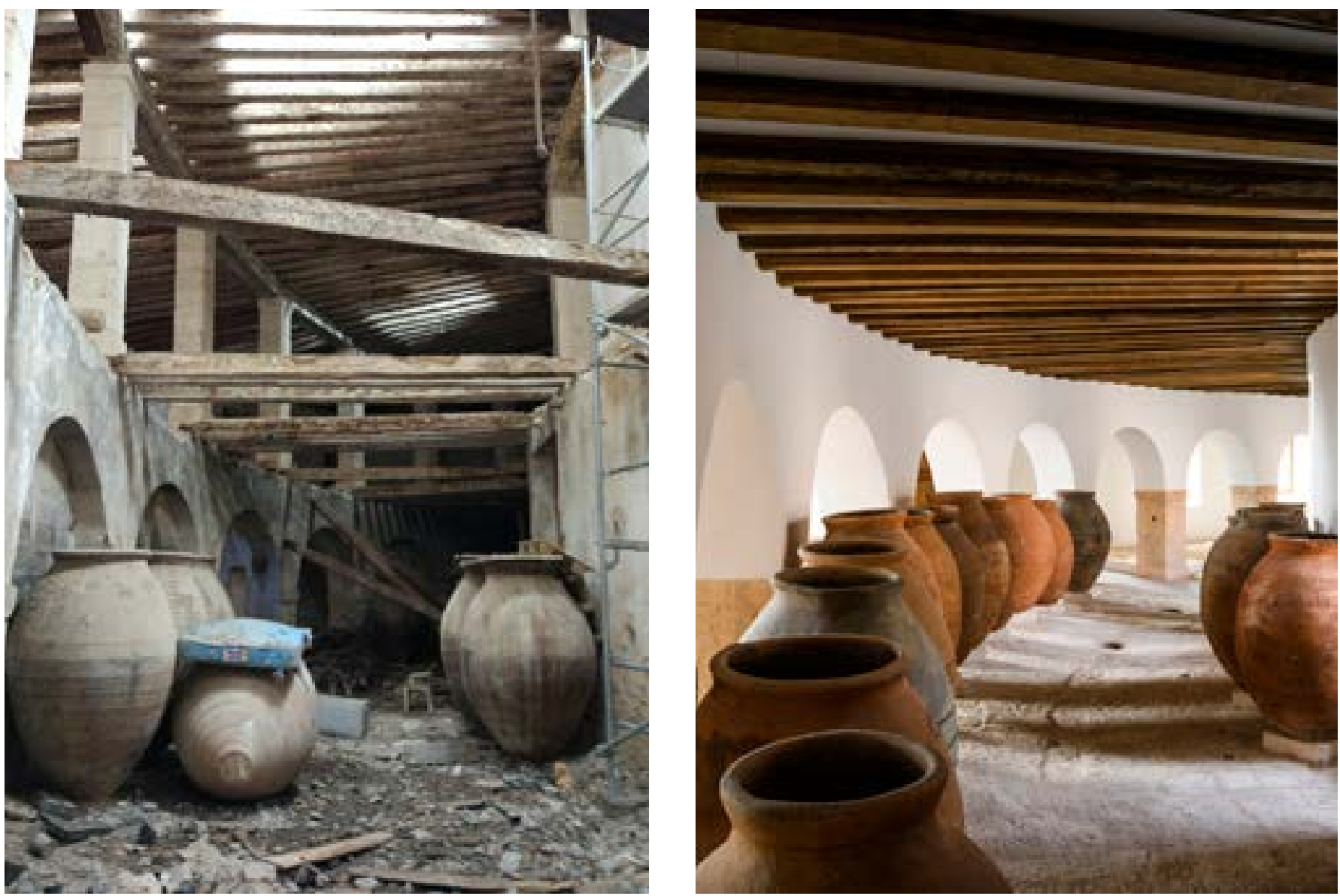


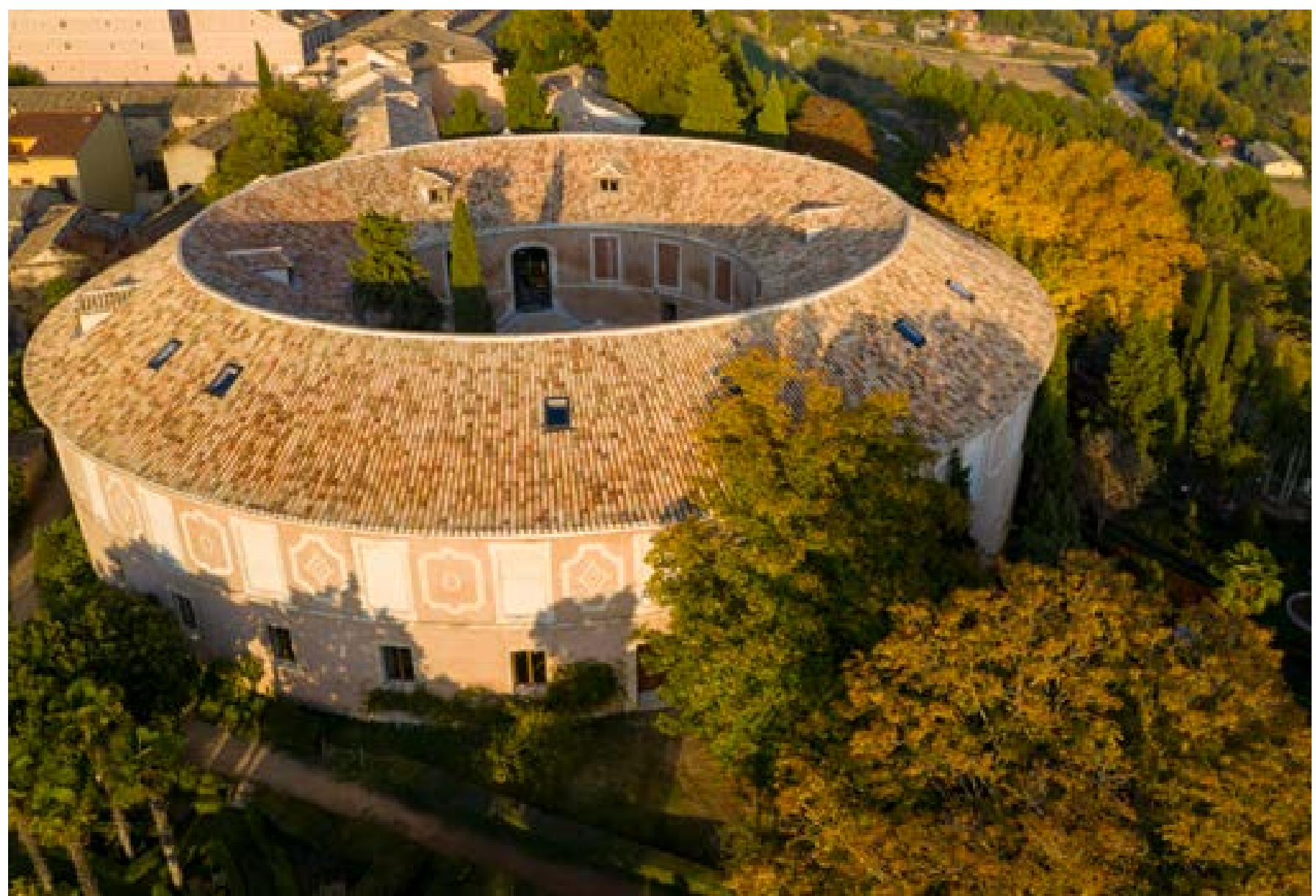

The Rotonda building after its restoration | Edificio de la Rotonda tras las obras de restauración | Edifício da Rotonda após as obras de restauração (Joaquín Zamora)

Finally, the crisis that struck at the turn of the century brought about a decrease in industrial activity. During the Spanish Independence War, the production of the Factory stopped and started its gradual decline until it was completely abandoned. During its long life, this singular industrial building was the subject of numerous interventions and maintenance works; the latest on record, previous to the one mentioned in this article, was commissioned in 1982 by the Dirección General de Bellas Artes to architects $M^{a}$ Carmen Mostaza and Andrés Perea, with the purpose of restoring the Rotonda buildings and the chapel. Even though the structure was consolidated and the roofs and façades were repaired, the proposed rehabilitation of the interior of the building was not carried out.
Finalmente, la crisis de final de siglo supuso una reducción de la actividad industrial y durante la Guerra de la Independencia cesó la producción de la Fábrica. A partir de entonces, fue cayendo en declive hasta su completo abandono. Durante su larga vida este singular edificio industrial ha sido objeto de diversas intervenciones y obras de mantenimiento; la última de la que se tiene constancia, previa a la que se refiere este artículo, es la que la Dirección General de Bellas Artes encargó en 1982 a los arquitectos Ma Carmen Mostaza y Andrés Perea, con el objetivo de restaurar los edificios de la Rotonda y la capilla. Aunque se consolidó la estructura y se arreglaron las cubiertas y fachadas, no se llevó a cabo la rehabilitación propuesta para el interior del inmueble.
Finalmente, a crise do final do século implicou uma redução da atividade industrial e durante a Guerra da Independência cessou a produção da Fábrica. A partir de então, foi caindo em declive até ao seu completo abandono. Durante a sua longa vida, este particular edifício industrial foi objeto de diversas intervenções e de obras de manutenção; a última da que se tem conhecimento, prévia à que se refere este artigo, é a que a Dirección General de Bellas Artes encarregou em 1982 aos arquitetos Maria Carmen Mostaza e Andrés Perea, com o objetivo de restaurarem os edifícios da Rotonda (o edifício de planta circular) e a capela. Ainda que se consolidasse a estrutura e se arranjassem as coberturas e fachadas, não se realizou a reabilitação proposta para o interior do imóvel. 


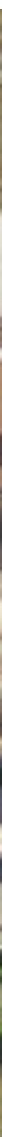

Aerial view of the Cloth Factory during the restoration works of the main building roofs | Imagen aérea de la Fábrica de Paños durante las obras de restauración de las cubiertas del edificio principal | Imagem aérea da Fábrica de Paños durante as obras de restauração das coberturas do edifício principal (Luis Fernando Abril)

The Cloth Factory ensemble is composed of several buildings. The main one is the Rotonda, which has a circular floor plan. Two functional linear elements branch out from it, the press and dyeing lines. This arrangement creates an ensemble structured around two interior patios: a rectangular one and a circular one. Around the latter, the Rotonda building is composed by masonry ring-shaped walls with a thickness of $1.60 \mathrm{~m}$ at the base, and a central structural ring made up by Alcarria stone pilasters at the lower floor that support a stone arcade. On the next floor, the structure of this central ring is lighter and the pilasters become stone pillars that support double timber beams. Finally the roof structure, also of wood, consists of a radial truss resting on pillars, each formed by an upright with struts on either side.
El conjunto de la Fábrica de Paños lo forman diferentes edificios. El principal es la Rotonda, de planta circular. De ésta nacen dos elementos funcionales lineales, que constituían los ramales de prensa y tintes. Con esta disposición de elementos se conforma un conjunto alrededor de dos patios interiores: uno rectangular y otro circular. En torno a este último patio, el edificio de la Rotonda está conformado por unos muros anulares realizados con mampostería, de 1,60 metros de espesor en su base, y un anillo central estructural formado por pilastras de piedra alcarreña en la planta inferior que soportan una arquería de mampuestos. En la siguiente planta la estructura de este anillo central se aligera y las pilastras pasan a transformarse en pilares de piedra sobre los que apoyan dobles vigas de madera. Finalmente, la estructura de cubierta, también de madera, está constituida por cuchillos radiales que apoyan sobre pilares, cada uno de ellos compuesto por un pie derecho con tornapuntas a ambos lados.
O conjunto da Fábrica de Paños está formado por diferentes edifícios. $\mathrm{O}$ principal é a Rotonda, de planta circular. Desta nascem os elementos funcionais lineais, que constituíam os ramais de prensa e tintas. Com esta disposição de elementos forma-se um conjunto à volta dos pátios interiores: um retangular e outro circular. À volta deste último pátio, o edifício da Rotonda está conformado por umas paredes anulares realizadas com alvenaria, de 1,60 metros de espessura na sua base, e um anel central estrutural formado por pilastras de pedra alcarrenha na planta inferior que suportam uma arcaria de blocos de pedra. No segundo piso, a estrutura deste anel central é aligeirada e as pilastras passam a transformar-se em pilares de pedra sobre os que apoiam vigas de madeira duplas. Por último, a estrutura da cobertura, também de madeira, está constituída por asnas radiais que apoiam sobre pilares, cada um deles composto por um pé direito com escoras em ambos lados. 
The current restoration works, commissioned by the City Council of Brihuega, were carried out on two consecutive phases: in the first and most urgent one, the restoration of the roofs and La Rotonda and the Dyes and Presses naves were completed. These works started in the last quarter of 2017 and lasted approximately one year. The second phase of interventions focused on the recovery of the lower floor, the access and the central patio of the Rotonda; these works started in February and were completed in October and were partially financed by funds from the Cultural 1.5\% Program of the Ministry of Public Works. The company in charge of the execution of all works was Lorquimur S.L., specialized in heritage restoration, which provided the appropriate staff for the execution of all works. Special
Las presentes obras de restauración, encargadas por el Excelentísimo Ayuntamiento de Brihuega, se han realizado en dos fases consecutivas: en la primera y más urgente se llevó a cabo la restauración de las cubiertas de la Rotonda y de las naves de Tintes y Prensas. Estas obras se iniciaron en el último trimestre de 2017 y tuvieron una duración aproximada de un año. La segunda fase de intervenciones se centró en la recuperación de la planta inferior, el acceso y el patio central de la Rotonda; estas obras comenzaron en febrero de 2019 y fueron culminadas en octubre del mismo año. Estos trabajos fueron parcialmente financiados por fondos procedentes del Programa 1,5\% Cultural del Ministerio de Fomento. La empresa especializada en restauración del patrimonio encargada de ejecutar todos los trabajos fue Lorquimur S.L.,
As presentes obras de restauração, encarregadas pelo Excelentíssimo Ayuntamiento de Brihuega, foram realizadas em duas fases consecutivas: na primeira e mais urgente foi realizada a restauração das coberturas da Rotonda e das naves de Tintas e Prensas. Estas obras iniciaram-se no último trimestre de 2017 e duraram aproximadamente um ano. A segunda fase de intervenção centrou-se na recuperação da planta inferior, do acesso e do pático central da Rotonda; estas obras começaram em fevereiro de 2019 e culminaram em outubro do mesmo ano. Estes trabalhos foram parcialmente financiados por fundos provenientes do Programa 1,5 $\%$ Cultural do Ministerio de Fomento. A empresa especializada em restauração do património encarregada de executar todos os trabalhos foi a Lorquimur S.L., a qual proporcionou pessoal especializado

Archaeological remains of old Factory partitions found after the works | Restos arqueológicos de antiguas particiones de la Fábrica encontrados tras las obras | Restos arqueológicos de antigas frações da Fábrica encontrados após as obras (Joaquín Zamora)

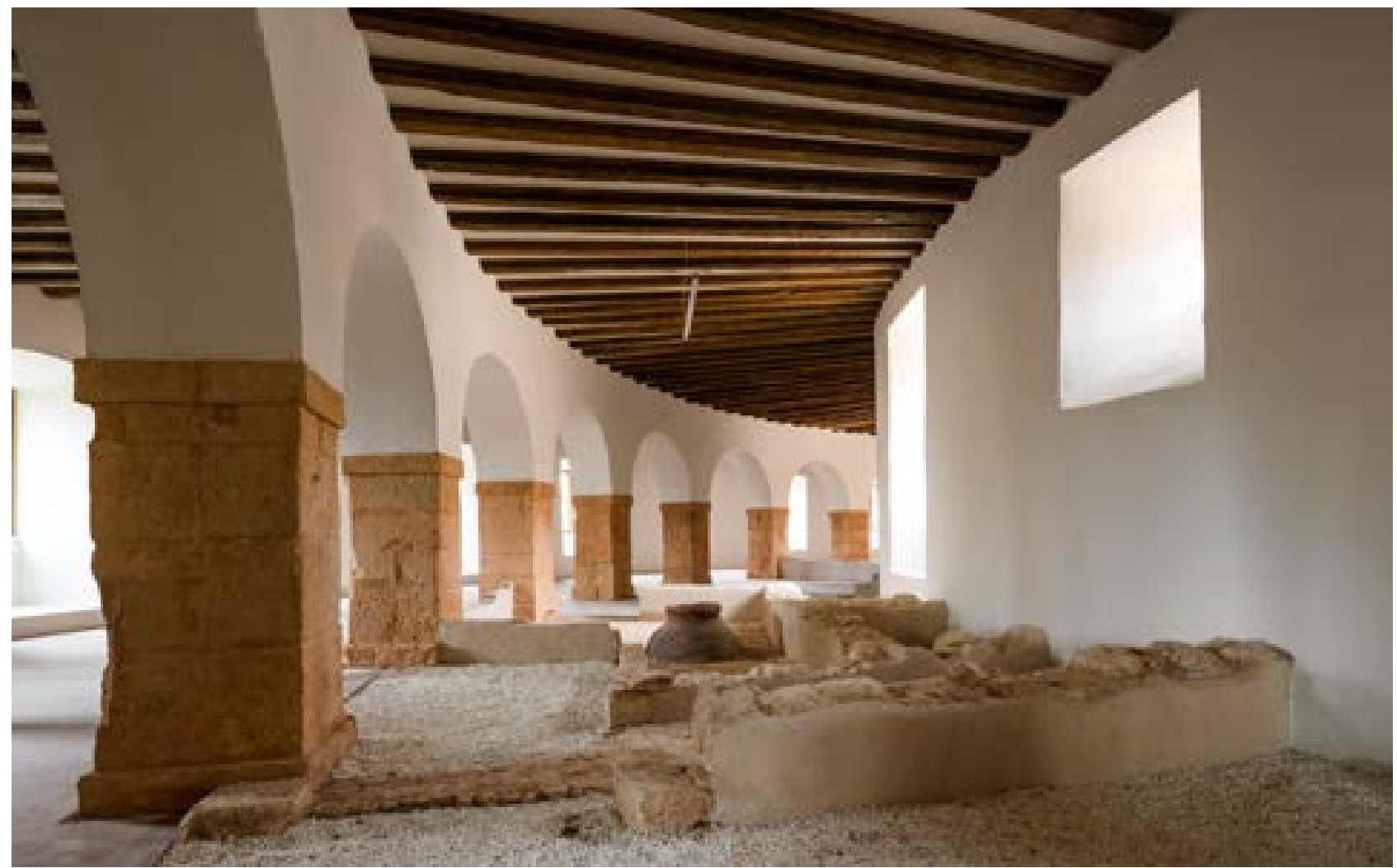


mention must be made of the handicraft work needed on the timber beams; the work of the carpenters made it possible to recover most of the existing beams through detailed and precise work on each of them.

The most appropriate methodology for intervening in this type of historical projects is always based on a prior exhaustive process of historical research, followed by field work necessary to draw up the planimetric survey and the pathological study. The main goal of this restoration was to bring back the identity of the building and to recover the rich spaces that had disappeared under the rubble. Thus, the work carried out was based on reconstruction and not on demolition, que aportó personal especializado para la ejecución de cada una de las labores. Especial mención merecen los trabajos de artesanía que hubieron de realizarse en las vigas de madera; el trabajo de los carpinteros permitió recuperar la inmensa mayoría de las vigas existentes mediante un preciso trabajo individualizado en cada una de ellas.

La metodología más adecuada para intervenir en este tipo de proyectos de carácter histórico parte siempre de un proceso previo de investigación histórica exhaustiva, al que sigue un trabajo de campo para la elaboración del levantamiento planimétrico y del estudio patológico. El objetivo principal en esta restauración fue devolver la identidad al edificio y recuperar toda la riqueza para a execução de cada um dos labores. Especial menção merecem os trabalhos de artesanato que se tiveram que realizar nas vigas de madeira; o trabalho dos carpinteiros permitiu recuperar a imensa maioria das vigas existentes mediante um preciso trabalho individualizado em cada uma delas.

A metodologia mais adequada para intervir neste tipo de projetos de carácter histórico parte sempre de um processo prévio de investigação histórica exaustiva, ao que se lhe segue um trabalho de campo para a elaboração do levantamento planimétrico e do estudo patológico. $\mathrm{O}$ objetivo principal nesta restauração era devolver a identidade ao edifício e recuperar toda a riqueza especial que tinha desaparecido entre os

Sketch of the interventions on the roof structure of the Rotonda Croquis de intervenciones sobre la estructura del techo de la planta primera de la Rotonda | Esboço de intervenções sobre a estrutura do teto da primeira planta da Rotonda

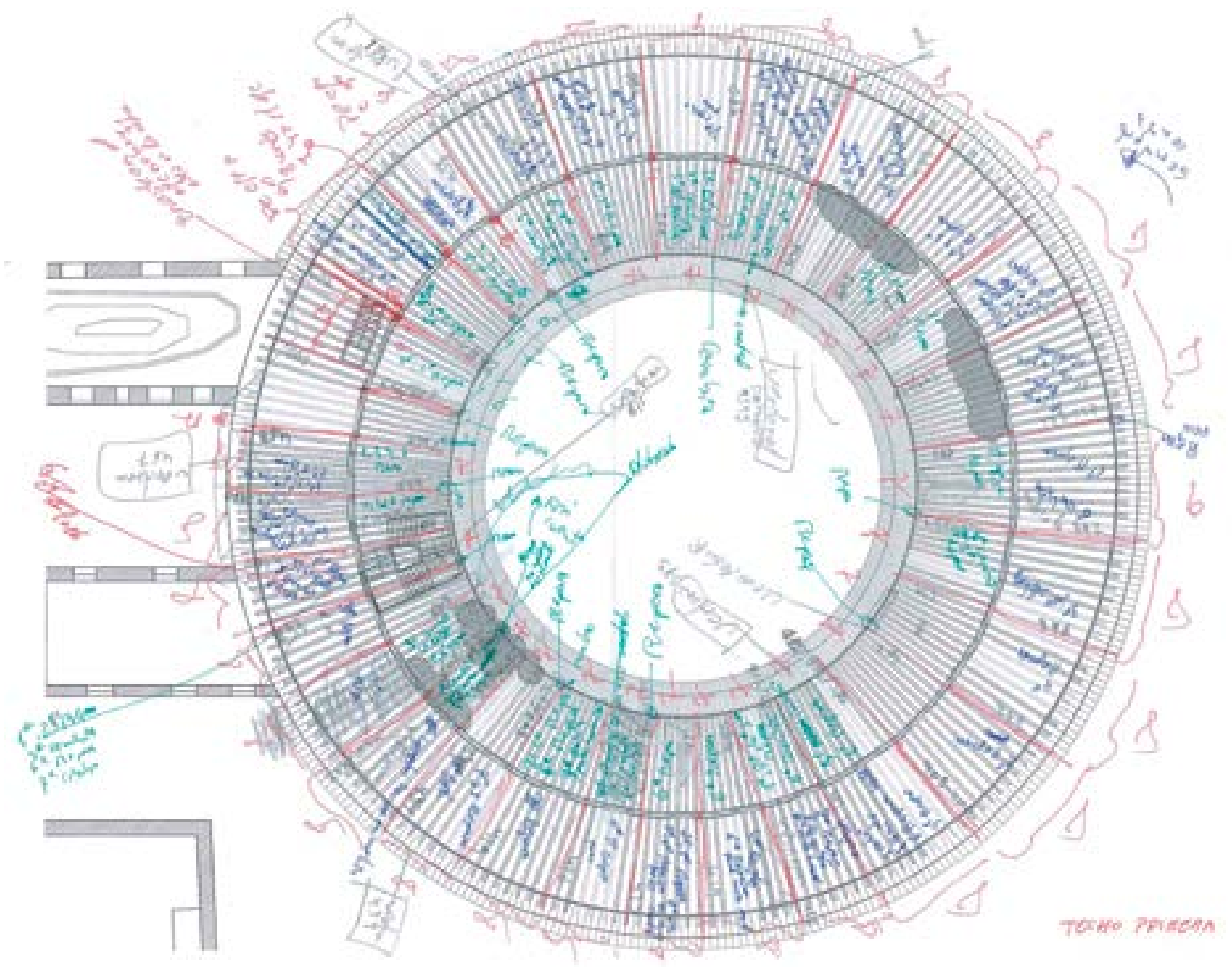



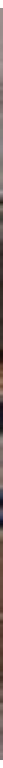

Recovery of the profiles on the deteriorated timber beams | Ejecución de las prótesis en las vigas de madera deterioradas | Execução das próteses nas vigas de madeira deterioradas

on the use of the same constructive systems and traditional materials found in the buildings, and on the integration of the archeological remains that appeared during the works, since they are also part of the history of the building. espacial que había desaparecido entre los escombros. Por ello, los trabajos llevados a cabo se basaron en la reconstrucción y no en la demolición, además de en el uso de los mismos sistemas constructivos y materiales tradicionales encontrados en el edificio y en la incorporación de los restos arqueológicos que aparecieron durante las obras, pues también forman parte de la historia del edificio. escombros. Por este motivo, os trabalhos realizados basearam-se na reconstrução e não na demolição, para além do emprego dos mesmos sistemas construtivos e materiais tradicionais encontrados no edifício e da incorporação dos restos arqueológicos que apareceram durante as obras, pois também formam parte da história do edifício.

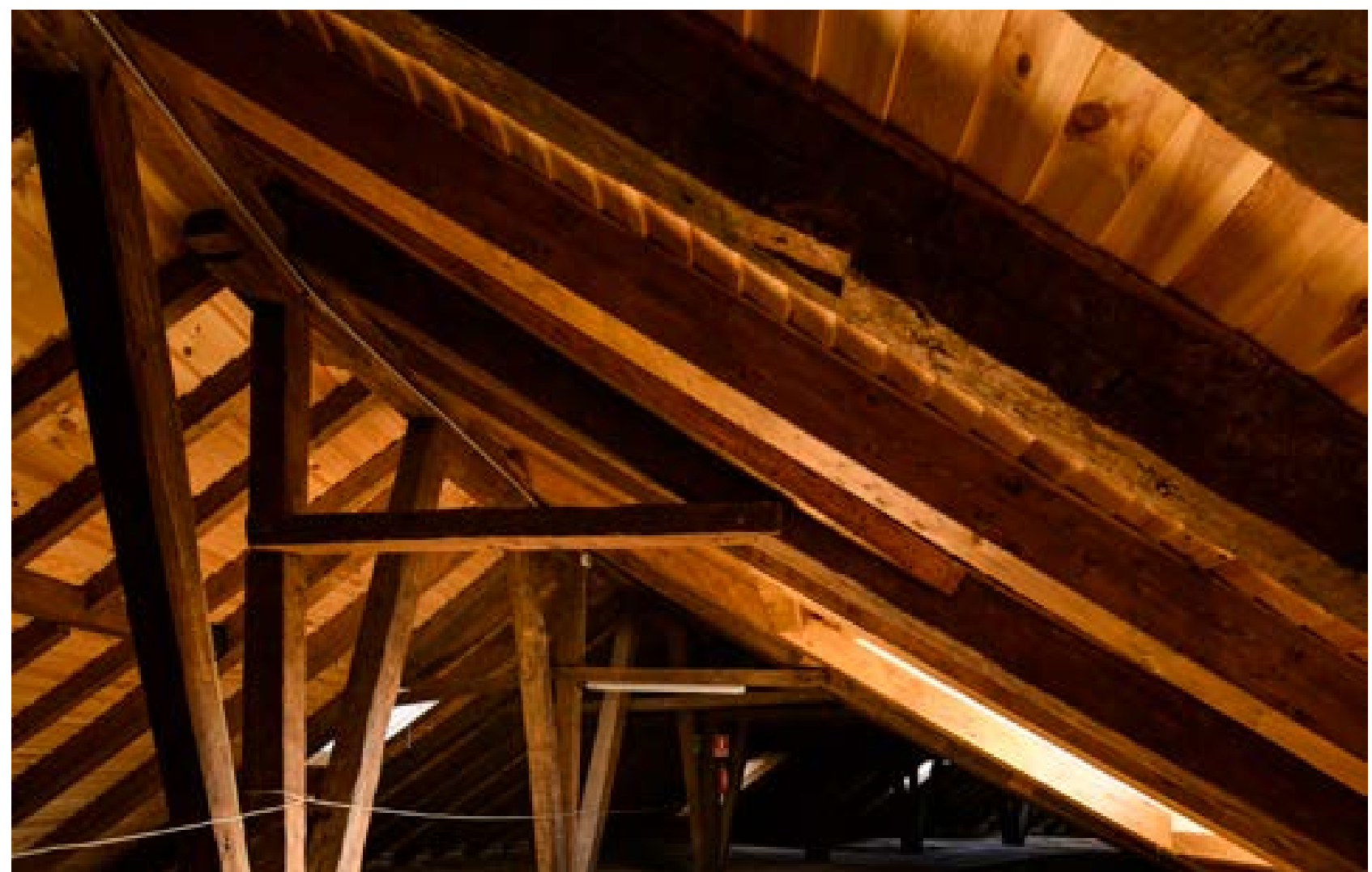



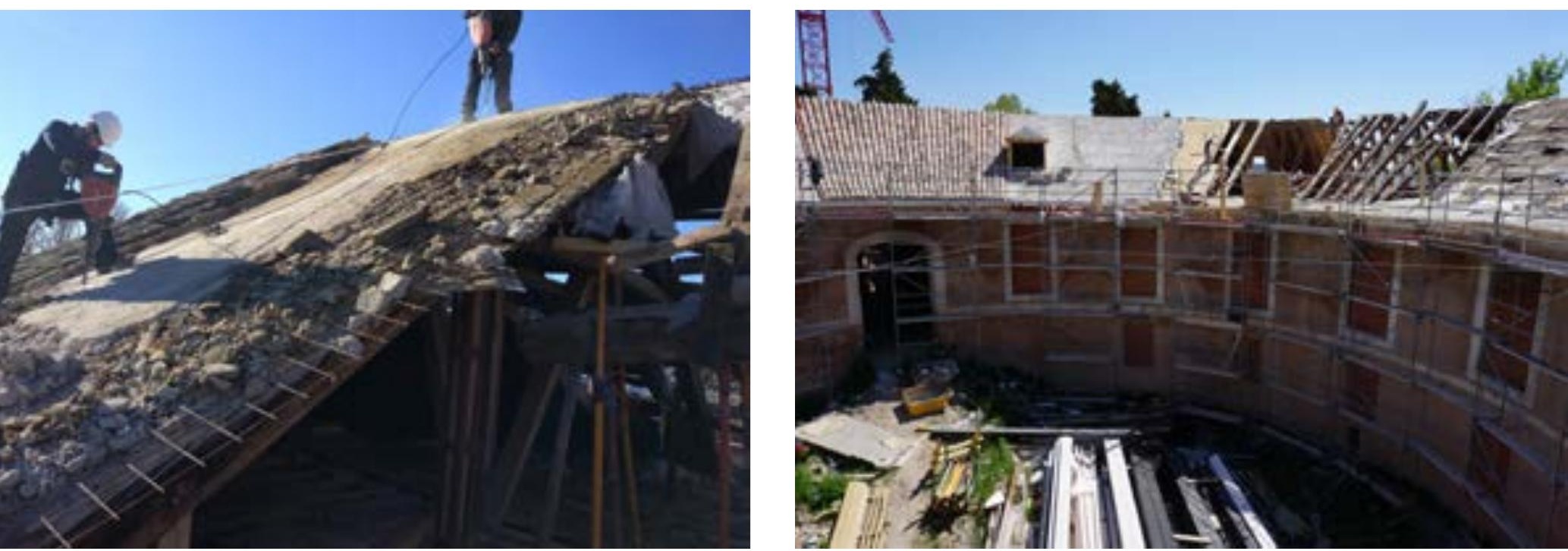

1: Removal of the concrete slab which was presumably added during the works carried out in the 80's 2: Image of the restoration of the Rotonda roof, showing the sequence of the works carried out, from the removal of the concrete slab and the timber remains (right) to the final retiling (left) $\mid 1$ : Retirada de la losa de hormigón ejecutada presumiblemente durante el transcurso de las obras llevadas a cabo en la década de los años ochenta 2: Imagen de la restauración de la cubierta de la rotonda, donde se aprecia la secuencia de los trabajos realizados, desde la retirada de la losa de hormigón y restos de tabla (derecha) hasta el retejado final (izquierda) | 1: Retirada da laje de betão executada supostamente durante o decorrer das obras efetuadas na década dos anos oitenta 2: Imagem da restauração da cobertura da Rotonda, onde se aprecia a sequencia dos trabalhos realizados, desde a retirada da laje de betão e restos de tábuas (direita) até ao retelhado final (esquerda)

The existing roof was a gable roof with ceramic tiles. Due to the previous interventions, the tiles stood on a reinforced concrete slab that generated excessive load on the load-bearing timber structure, as well as the inappropriate stiffening of the whole constructive system. Numerous timber beams had collapsed as a result of the introduction of this system. This led to the complete disappearance of some areas of the roof that let water come in, seriously damaging the interior of the building.

The current restoration, therefore, started with the removal of this rigid concrete slab that did not fit with the much more flexible timber structure and generated a huge load on the latter, and with the removal of a huge perimeter concrete ring that had caused all the rafters to rot. Once this initial work was completed, the elements that were in a bad condition were repaired and consolidated, the timber structure was restored, and the roof was retiled. The original tiles were reused for that purpose and the original timber structure, as well as the traditional joints were preserved as far as possible. This was a particularly delicate work,
La cubierta existente estaba construida a dos aguas con teja árabe. A causa de las intervenciones precedentes, esta cubierta se encontraba colocada sobre una solera armada de hormigón que generaba una carga excesiva en la estructura portante de madera, además de una rigidización inapropiada de todo el sistema constructivo. Debido a la introducción de este sistema, muchas de las vigas de madera habían colapsado. Esto había ocasionado la desaparición completa de algunos paños, por cuyos huecos entraba el agua, que provocaba a su paso gravísimos daños en el interior del edificio.

La presente restauración comenzó, por tanto, por la retirada de esa solera de hormigón rígida que no colaboraba con la estructura de madera, mucho más flexible, y que además generaba una carga enorme sobre ésta, así como por la eliminación de un enorme zuncho en los bordes que había provocado la pudrición de todas las vigas de los pares. Completados estos primeros trabajos, se repararon y consolidaron los elementos en mal estado, y una vez restituida la estructura de madera, y se volvió a retejar. Para ello se reutilizaron las tejas existentes y se conservó al máximo posible toda la
A cobertura existente estava construída a duas águas com telha árabe. Nas intervenções precedentes, uma placa de betão armado tinha sido colocada sobre esta cobertura, o que gerava uma carga excessiva na estrutura portante de madeira das armações, para além de uma rigidez inapropriada de todo o sistema construtivo. Devido à introdução deste sistema, muitas das vigas de madeira tinham-se desmoronado. Isto provocou a desaparição completa de alguns panos, por cujas aberturas entrava a água, causando durante a sua passagem gravíssimos danos no interior do edifício.

A presente restauração começou, portanto, com a retirada dessa placa de betão rígido que não colaborava com a estrutura de madeira, bem mais flexível, e que também criava uma carga enorme sobre esta, bem como pela eliminação de uma enorme viga nas bordas que tinha provocado o apodrecimento de todas as vigas das varas. Uma vez completado estes primeiros trabalhos, os elementos em mau estado foram reparados e consolidados, e uma vez restituída a estrutura de madeira, voltou-se a retelhar. Para isso, utilizaram-se as telhas existentes e conservou-se ao máximo possível toda a estrutura de madeira 
for the goal was to preserve as many of the original beams as possible, and to this end an on-site workshop was set up to produce glued wood profiles with a thickness of five centimeters which were used until the missing volumes were filled out.
1: Pilasters of the arcades buried under the rubble; state before the second phase 2: Ground floor arcade with its actual scale after restoration works | 1: Pilastras de las arcadas enterradas bajo escombros: estado previo a la segunda fase 2: Arcada de planta baja con su escala real tras las obras de restauración | 1: Pilastras das arcadas enterradas sob os escombros: estado antes da segunda fase 2: Arcadas da planta térrea à escala real após as obras de restauração (Joaquín Zamora) estructura de madera original, así como los ensambles tradicionales. Esta labor fue especialmente delicada, ya que el objetivo era mantener el mayor número posible de palos originales, por lo que se organizó un taller a pie de obra donde se realizaron prótesis de madera encolada con espesores de unos cinco centímetros hasta completar los volúmenes faltantes. original, bem como os ensambles tradicionais. Este labor foi especialmente delicado, já que o objetivo era manter o maior número possível de paus originais, pelo que se organizou uma oficina ao lado da obra onde se realizaram próteses de madeira colada com espessuras de uns cinco centímetros até completar o volume em falta.
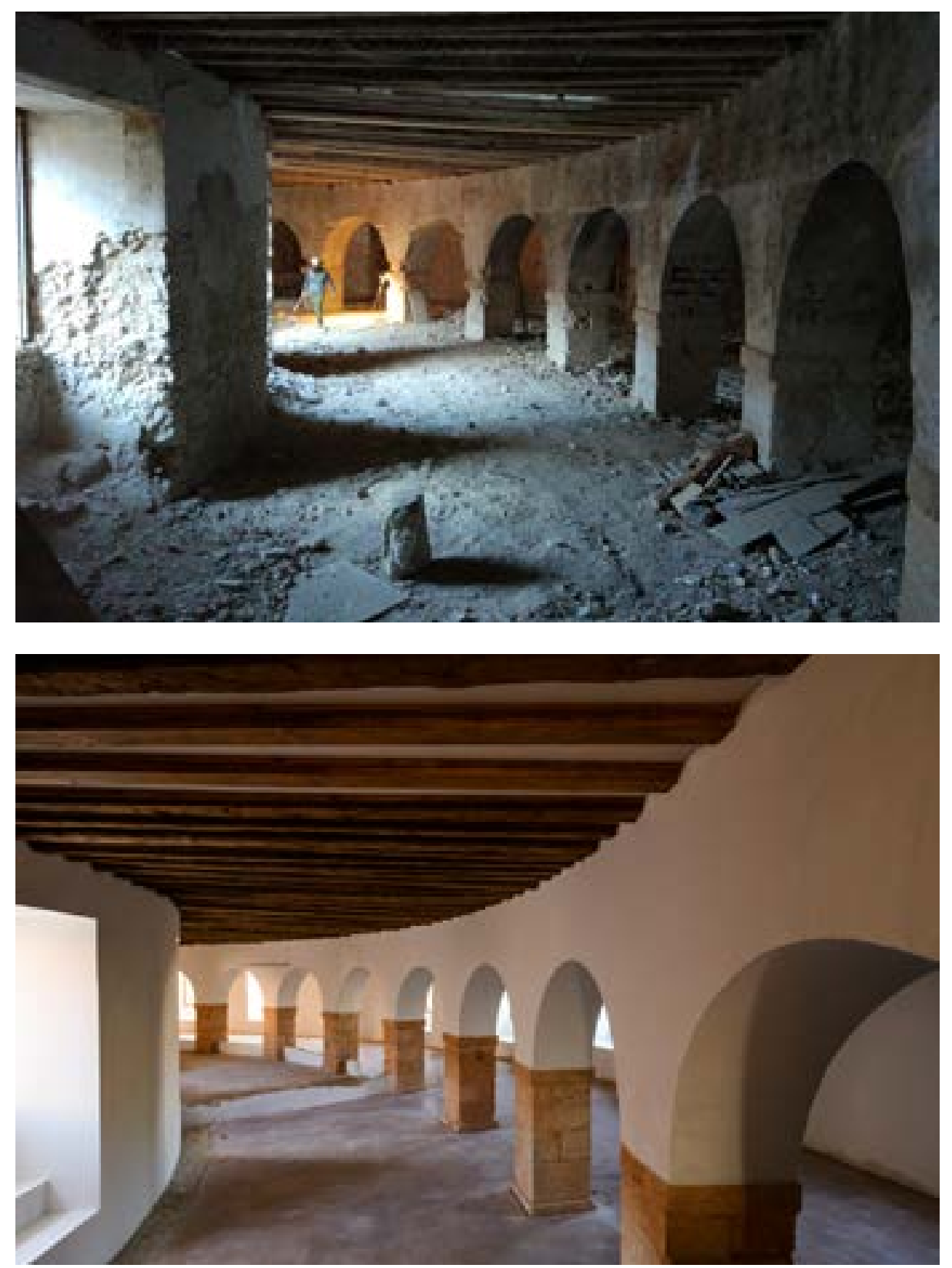
Once the roofs of the Rotonda building and of the press and dyeing naves were restored, and the progressive deterioration of the ensemble had been contained, the following works, which focused on the ground floors, could be carried out. Large amounts of filling were removed at the lowest floor, which revealed remains of the original structure and partitions of the spaces of the Factory, as well as remains of jars and old stone and ceramic floors. The removal of rubble also allowed the recovery of the actual scale of the arches, whose pilasters were buried under one meter of fillings. The restoration prioritized the use of traditional materials and techniques, and this made it possible to recover the lost ashlars that make up the ground
Una vez restauradas las cubiertas del edificio de la Rotonda y de las naves de prensa y tintes, y contenido con ello el progresivo deterioro del conjunto, se pudieron ejecutar los trabajos siguientes, centrados en las plantas bajas. En la planta inferior se retiraron primero grandes cantidades de relleno, lo que dejó al descubierto restos de la estructura original y particiones de los espacios que comprendía la Fábrica, así como restos de tinajas y antiguos solados de piedra y cerámicos. La retirada de escombros también permitió recuperar la escala real de los arcos, cuyas pilastras se encontraban enterradas bajo un metro de rellenos. En su restauración primó el empleo de materiales y técnicas tradicionales, por lo que se pudo recuperar íntegramente con cantería la
Uma vez restauradas as coberturas do edifício da Rotonda e das naves de prensa e tintas, e contido com isso o progressivo deterioramento do conjunto, foi possível executar os trabalhos seguintes, centrados nas plantas térreas. Na planta inferior foram retiradas primeiro grandes quantidades de enchimento, o que deixou ao descoberto restos da estrutura original e partições dos espaços que compreendia a Fábrica, bem como restos de ânforas e antigos pavimentos de pedra e cerâmica. A retirada de escombros também permitiu recuperar a escala real dos arcos, cujas pilastras se encontravam enterradas sob um metro de enchimentos. Na sua restauração primou o emprego de materiais e técnicas tradicionais, pelo que se pôde recuperar integramente com cantaria a pedreira

Orthophoto of the Rotonda patio with the restored pool and access staircase | Ortofoto del patio de la Rotonda con la alberca y la escalera de acceso restauradas | Ortofotografia do pátio da Rotonda com a alberca e a escada de acesso restauradas (Joaquín Zamora)

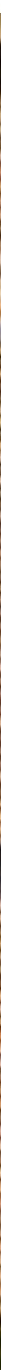


floor arcade and the pillars of the first floor using stonework. Applying the same criteria as that used for the roof, the original timber structure of the floors was preserved as much as possible, and a detailed study was made of the beams that were in poor condition. Thus, it was possible to work on the beams whose ends had been affected by the action of water and reinforced concrete, for which glued timber profiles were made until the deteriorated section was filled in.

The intervention on the patio included an archaeological dig, which allowed for the recovery of the old pool and the steps and the handrail connecting the different levels, which had disappeared and only a few remains had survived. It is important to note that water was a necessary element inside the building for the manufacture of clothes, and the interior spouts and water canals were also recovered. In order to avoid moisture, traditional lime and plaster coatings were used, and a ventilated floor system was built that allows the building to breathe and avoids the formation of moisture inside it.

At the time of writing this article, a final phase of construction is pending, that will restore the first floor and all the façades and existing exterior and interior woodwork, and will provide the building with the appropriate facilities for the use for which it is intended. sillería perdida en las pilastras que forman la arcada de la planta baja y los pilares de la planta primera. Con el mismo criterio de actuación que en la cubierta, se conservó lo máximo posible la estructura original de madera de los forjados y se realizó un estudio cuidadoso de las vigas que se encontraban en mal estado. Se pudo intervenir así sobre aquellas cuyas cabezas se habían visto afectadas por la acción del agua o del hormigón armado, para lo que se ejecutaron prótesis de madera encolada hasta completar la sección deteriorada.

La actuación sobre el patio incluyó su excavación arqueológica, lo que permitió recuperar la antigua alberca, así como los peldaños y barandilla de conexión entre los niveles, que habían desaparecido y de los que sólo quedaban huellas. Es importante recordar que el agua era un elemento necesario en el interior del edificio para fabricar las telas, por lo que también se recuperaron las gárgolas y canales interiores por los que discurría. Para evitar la aparición de humedades se utilizaron revestimientos tradicionales de cal y yeso y se realizó un sistema de solera ventilada que contribuye a que el edificio pueda respirar y no se genere humedad en su interior.

En el momento de redacción de este artículo queda pendiente una última fase de construcción, que permita restaurar la planta primera, así como la totalidad de las fachadas y carpinterías exteriores e interiores, y que doten al edificio de unas instalaciones adecuadas al uso al que se destine. perdida nas pilastras que formam a arcada da planta térrea e dos pilares da primeira planta. Com o mesmo critério de atuação que na cobertura, conservouse ao máximo possível a estrutura original de madeira das armaçoes e realizou-se um estudo cuidadoso daquelas vigas que se encontravam em mal estado. Foi possível intervir assim sobre aquelas cujas cabeças tinham sido afetadas pela ação da água ou do betão armado, pelo que se executaram próteses de madeira colada até completar a secção deteriorada.

A intervenção no pátio incluiu a sua escavação arqueológica, o que permitiu recuperar a antiga alberca, bem como as escadas e o gradil de conexão entre os níveis que tinham desaparecido e dos que apenas ficaram marcas. É importante recordar que a água era um elemento necessário no interior do edifício para fabricar os tecidos, pelo que também foram recuperadas as gárgulas e os canais interiores por onde fluía. Para evitar o aparecimento de humidade foram utilizados revestimentos tradicionais de cal e gesso, e realizou-se um sistema de placa ventilada que contribui para que o edifício possa respirar e não crie humidade no seu interior.

Aquando da redação deste artículo, estava pendente a última fase de construção, que permitisse restaurar a primeira planta, bem como a totalidade das suas fachadas e da carpintaria exterior e interior, e que dotem ao edifício de umas instalações adequadas à utilização que seja destinada.

\section{References $\mid$ Referencias $\mid$ Referências}

Agustí, Ernesto; Forteza, Cristina; Calvo, Jorge; Morín, Jorge; Cantallops, Laura; López, Francisco; y Hernández, María; 2007. Obras públicas de la Ilustración española. La Real Fábrica de Paños de Brihuega (Guadalajara). Actas de las II Jornadas de Arqueología de Castilla-La Mancha. Toledo: Diputación Provincial de Toledo.

Herrera Casado, Antonio. 1995. Brihuega, la roca del Tajuña (Colección Tierra de Guadalajara, nº 14). Guadalajara: AACHE.

De la Hoz Martínez, Juan de Dios. 2019. La restauración de la Real Fábrica de paños de Carlos III en Brihuega. IV Jornadas de Turismo y Patrimonio Industrial. Área de Turismo del Ayuntamiento de Segovia. 


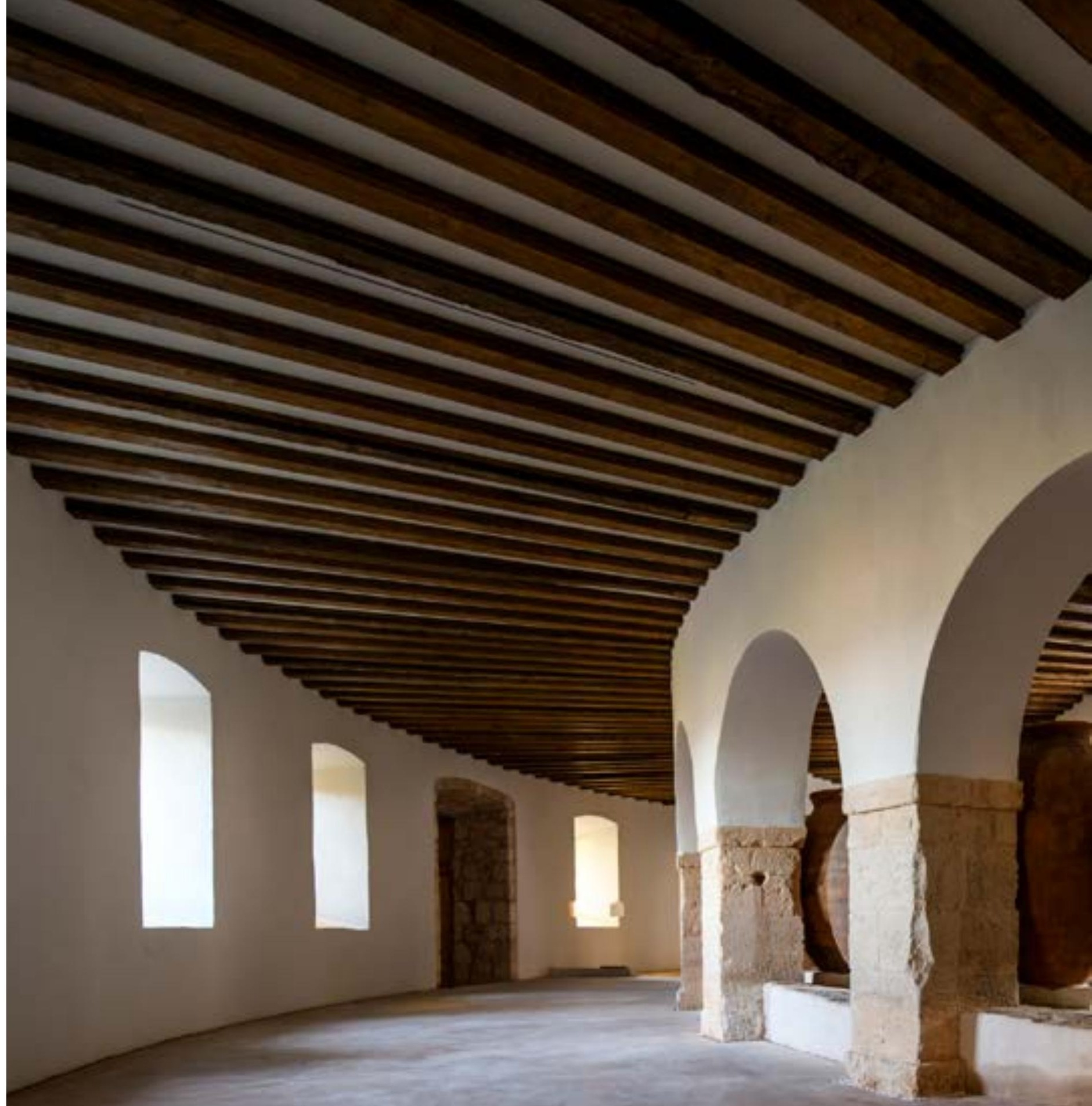

Biography $\mid$ Biografía $\mid$ Biografia

\section{Juan de Dios de la Hoz Martínez}

Architect since 1988. He is specialized in interventions for the recovery of heritage buildings, he has directed more than one hundred restoration projects on different Monuments and Assets of Cultural Interest, such as the Alcalá de Henares, Murcia and Almería Cathedrals and the Metropolitan Cathedral in Panama; the San Jerónimo de Yuste Monastery, the Colegio Español de Santiago y Montserrat in Rome; castles and fortresses such as those of Belmonte (Cuenca), Brihuega (Guadalajara), Caravaca de la Cruz (Murcia), Alcalá de Henares (Madrid), Teguise (Lanzarote) or Tabernas (Almería). He was awarded the Europa Nostra Prize 2016 for his work on the churches of Lorca after the earthquakes in 2011, the European Union Restoration Prize for his intervention at the Alcalá de Henares Cathedral, the Building Quality Prize from the Region of Murcia for the Museum of the Fine Arts of Murcia, the 2016 Culture Prize from the Region of Madrid for his professional career specialized in heritage, and the 2018 Rafael Manzano Prize for New Traditional Architecture for his professional career.

Es arquitecto desde 1988. Está especializado en intervenciones de recuperación de inmuebles integrantes del Patrimonio Histórico y ha dirigido más de un centenar de obras de restauración en diferentes Monumentos y Bienes de Interés Cultural, como las catedrales de Alcalá de Henares, Murcia, Almería o la Metropolitana en Panamá; el Monasterio de San Jerónimo de Yuste o el Colegio Español de Santiago y Montserrat en Roma; y castillos y fortalezas como 


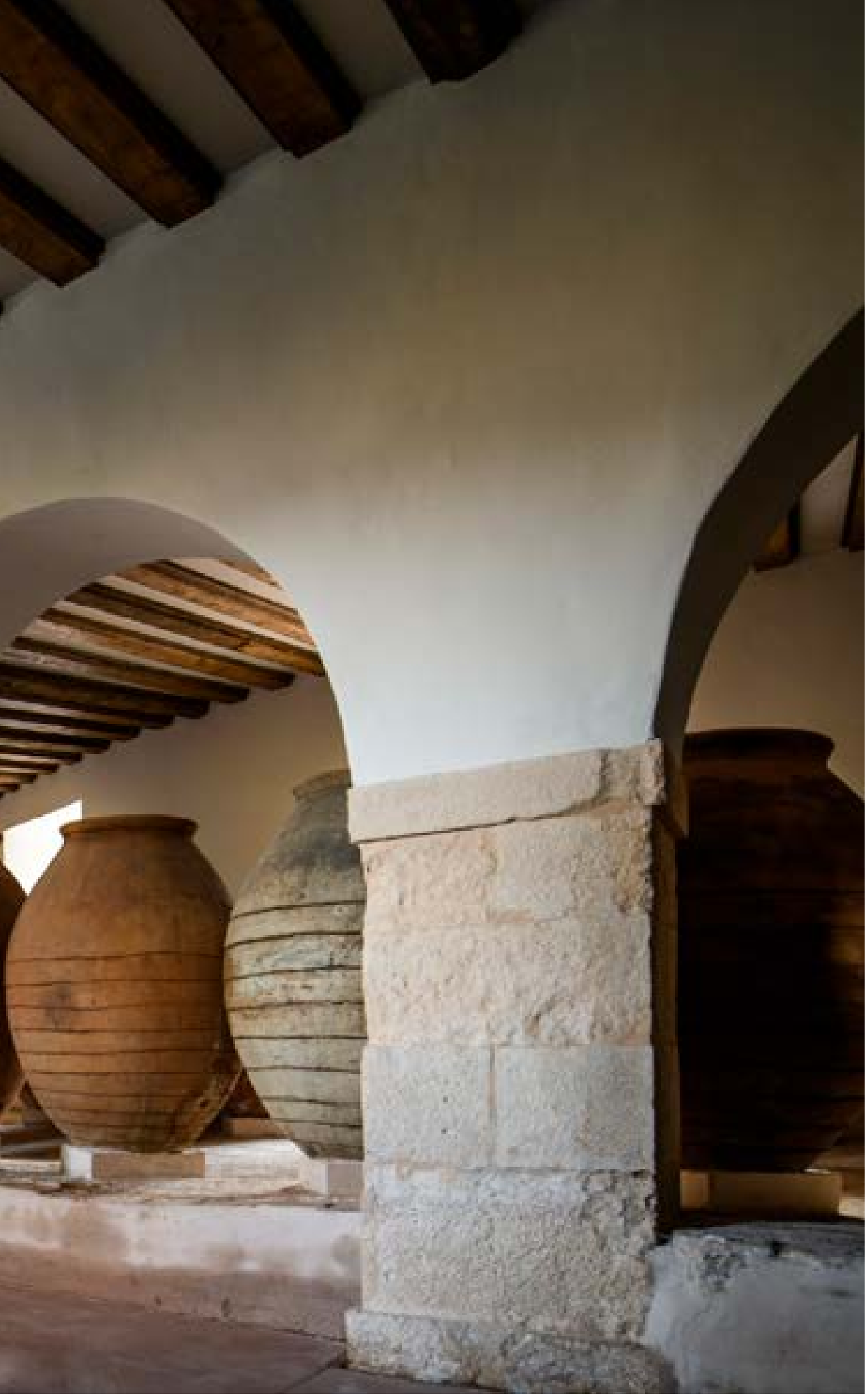

Works | Obras

Interior space of the Rotonda after restoration | Espacio interior de la Rotonda tras las obras de restauración | Espaço interior da Rotonda após as obras de restauração (Joaquín Zamora)

los de Belmonte (Cuenca), Brihuega (Guadalajara), Caravaca de la Cruz (Murcia), Alcalá de Henares (Madrid), Teguise (Lanzarote) o Tabernas (Almería). Ha recibido el Premio Europa Nostra 2016 por sus actuaciones en las iglesias de Lorca tras los terremotos de 2011, el Premio de restauración de la Unión Europea por su intervención en la Catedral de Alcalá de Henares, el Premio a la Calidad en la Edificación de la Región de Murcia por el Museo de Bellas Artes de Murcia, el Premio de Cultura de la Comunidad de Madrid (2016) por su trayectoria profesional en la especialidad de Patrimonio Histórico, y el Premio Rafael Manzano de Nueva Arquitectura Tradicional (2018) también por el conjunto de su obra.

Arquiteto desde 1988. Especializou-se na intervenção de recuperação de imóveis integrantes do Património Histórico e dirigiu mais de um centenar de obras de restauração em diferentes Monumentos e Bens de Interesse Cultural, como as catedrais de Alcalá de Henares, Múrcia, Almeria ou a Metropolitana em Panamá; o Mosteiro de San Jerónimo de Yuste ou o Colégio Español de Santiago e Monteserrat em Roma; e castelos e fortalezas como os de Belmonte (Cuenca), Brihuega (Guadalajara), Caravaca de la Cruz (Múrcia), Alcalá de Henares (Madrid), Teguise (Lanzarote) ou Tabernas (Almeria). Recebeu o Prémio Europa Nostra 2016 pelas suas ações nas igrejas de Lorca após os terramotos de 2011, o Prémio de restauração da União Europeia pela sua intervenção na Catedral de Alcalá de Henares, o Prémio à Qualidade na Edificação da Região de Múrcia pelo Museu de Belas Artes de Múrcia, o Prémio de Cultura da Comunidade de Madrid (2016) pela sua trajetória profissional na especialidade de Património Histórico, e o Prémio Rafael Manzano de Nueva Arquitectura Tradicional (2018) também pelo conjunto da sua obra. 